\title{
Protein Aggregation: A New Challenge in Type-II Diabetes
}

\author{
Ejazul Haque ${ }^{1}$, Mohd Kamil ${ }^{1}$, Safia Irfan ${ }^{1}$, Adria Hasan ${ }^{2}$, Saba Sheikh ${ }^{1}$ and Snober S Mir ${ }^{2 *}$ \\ ${ }^{1}$ Department of Biosciences, Integral University, India \\ ${ }^{2}$ Department of Bioengineering, Integral University, India
}

Submission: February 23, 2017; Published: April 05, 2017

*Corresponding author: Snober S Mir, Associate Professor, Department of Bioengineering, Faculty of Engineering, Integral University, Lucknow 226026, India, Email: smir@iul.ac.in

\begin{abstract}
Accumulation of misfolded proteins or their aggregates in various organs is the hallmark of protein misfolding disorders (PMD), including Alzheimer's and Parkinson's Diseases. Recent studies have shown accumulation of protein aggregates in some non-neurodegenerative diseases like cancer and type-II diabetes. Deposition of toxic aggregates of islet amyloid polypeptide (IAPP) or amylin may cause dysfunctioning and loss of $\beta$-cells leading to impaired insulin release and cause type-II diabetes. In this review, we will discuss the aggregation of islet amyloid polypeptide (IAPP) or amylin and associated toxicity in pancreas promoting type-II diabetes.
\end{abstract}

Keywords: Protein aggregation; Islet amyloid polypeptide (IAPP) or Amylin; Type-II diabetes

\section{Introduction}

From many decades, researchers have been aware of the formation of insoluble protein aggregates in many neurodegenerative diseases such as Parkinson's, Alzheimer's and Huntington's diseases [1] but there are some reports which showed the presence of insoluble amyloid deposits in diabetes mellitus type 2 . Diabetes is a very common but a serious chronic disease in which either body can't produce enough insulin (Type-I Diabetes) or doesn't properly use the insulin it produces (Type-II Diabetes) [2]. According to WHO report (2014), about 422 million people over the age of 18 were suffering from diabetes throughout the world [3] out of which type-II diabetes accounts for the vast majority of people around the world [2]. A common pathology shared among type II diabetic patients is the accumulation of islet amyloid polypeptide (IAPP, also known as amylin) in an insoluble fibrillar form in the pancreas [4]. Similar accumulations of misfolded amyloid proteins have also been found to be characteristic of other diseases that strike primarily late in life, including Alzheimer's, Parkinson's, and Huntington's diseases [1]. Self aggregation of human islet amyloid polypeptide (hIAPP) is associated with the development of type-II diabetes by the disturbance of cellular homeostasis in islet cells through the formation of oligomers $[5,6]$.

\section{Discussion}

Human islet amyloid polypeptide (hIAPP) or Amylin, is a small neuroendocrine polypeptide hormone (37 amino acid) secreted by pancreatic $\beta$-cells that form aggregates under insulin deficiency metabolic conditions. Accumulating data suggests that toxic aggregates of IAPP may contribute to $\beta$-cell dysfunction and disease $[7,8]$. More recently, it has been recognized that amylin deposits are actually present in more than $90 \%$ of typeII diabetes patients [9] hence these reports strongly suggest that these aggregates become a pathological hallmark of typeII diabetes. The important question is whether these aggregates act as inert bystanders that result due to tissue damage during the disease, or whether they play a vital role in type-II diabetes pathogenesis. For this many studies have been performed. One longitudinal study showed that formation of IAPP aggregates precede $\beta$-cell dysfunction and clinical signs of the disease in animal models that spontaneously develop type-II diabetes (non-human primates and domestic cats)[9]. Ttransgenic mice and rats over expressing human IAPP spontaneously developed clinical and pathological hallmarks of type-II diabetes [10].

Previously, the general notion was that the fibrillar from of amylin is toxic but the current consensus support that the 
oligomeric form of amylin exerts toxic effect [11]. The exact mechanism behind the amylin aggregates mediated destruction of beta cells was not clearly understood. There are various assumptions regarding its mechanism. The first mechanism is that amylin aggregates disrupt cell membrane and subsequent imbalance of intracellular homeostasis thereby causing pancreatic cell death [12]. The second mechanism demonstrates that amylin aggregates promote pores or channels formation in lipid bilayer $[13,14]$ resulting cell death. These are the most accepted cytotoxic mechanisms of amylin aggregates. There are some other suggested mechanisms for amylin aggregates mediated cytotoxicity which includes an ER stress response [15], activations of stress-activated kinases [16] and induction of reactive oxidative stress species or radicals $[17,18]$. It is also possible that all these mechanisms could work together to result in cell death ultimately . On this basis, considering type-II diabetes as a protein misfolding disorder will open an entirely new area of research and uncover novel targets for therapeutic intervention.

\section{Conclusion}

Amylin aggregation has been suggested to be toxic for pancreatic $\beta$ cells. Destruction of these pancreatic beta cells results in decreased insulin production and manifests as typeII diabetes. Now these days, metformin and insulin are most commonly used treatment for diabetes. Although these two therapeutic agents help to manage the disease, they do not prevent progression nor do they cure the disease. The exact mechanism and factors implicated in the transition from prediabetic conditions to $\beta$-cell failure and type-II diabetes are still not clear. So we should divert our focus in discovering a permanent cure for type-II diabetes and targeting amylin aggregation may be an answer to this question.

\section{Acknowledgement}

The authors are grateful to Hon'ble Vice Chancellor, Integral University, Lucknow for necessary infrastructural support. For the financial assistance, we are thankful to Science \& Engineering Research Board (SERB-DST) for the research grant (YSS/2015/001902), Department of Biotechnology (102/IFD/ SAN/3599/2013-2014 dated October 14, 2013. (Serial. No 110) and University Grants Commission (UGC), Government of India for providing Maulana Azad National Fellowship to the authors.

\section{References}

1. Chiti F, Dobson CM (2006) Protein misfolding, functional amyloid, and human disease. Annu. Rev. Biochem 75: 333-366.

2. World Health Organization (1999) (Definition, Diagnosis and Classification of Diabetes Mellitus and its Complications. Part 1: Diagnosis and Classification of Diabetes Mellitus (WHO/NCD/ NCS/99.2) Geneva, Switzerland.

3. NCD Risk Factor Collaboration (NCD-RisC) (2016) Worldwide trends in diabetes since 1980: a pooled analysis of 751 population-based studies with 4.4 million participants. Lancet 387(10027): 1513-1530.
4. Lorenzo A, Razzaboni B, Weir GC, Yankner BA (1994) Pancreatic islet cell toxicity of amylin associated with type-2 diabetes mellitus. Nature 368(6473): 756-760.

5. Westermark P, Wernstedt C, Wilander E, Hayden DW, O'Brien TD, et al. (1987) Amyloid fibrils in human insulinoma and islets of Langerhans of the diabetic cat are derived from a neuropeptide-like protein also present in normal islet cells. Proc Natl Acad Sci USA 84(11): 38813885.

6. Cooper GJ, Leighton B, Dimitriadis GD, Parry-Billings M, Kowalchuk JM, et al. (1988) Amylin found in amyloid deposits in human type 2 diabetes mellitus may be a hormone that regulates glycogen metabolism in skeletal muscle. Proc Natl Acad Sci USA 85(20): 7763-7766.

7. Haataja L, Gurlo T, Huang CJ, Butler PC (2008) Islet amyloid in type 2 diabetes, and the toxic oligomer hypothesis. Endocr Rev. 29(3): 303316.

8. Hull RL, Westermark GT, Westermark P, Kahn SE (2004) Islet amyloid: a critical entity in the pathogenesis of type 2 diabetes. J Clin Endocrinol Metab 89(8): 3629-3643.

9. Mukheerjee A, Morales-Scheihing D, Butler PC, Soto C (2016) Type 2 Diabetes as a Protein Misfolding Disease. Trends Mol Med 21(7): 439449.

10. Janson J, Soeller WC, Roche PC, Nelson RT, Torchia AJ et al. (1996) Spontaneous diabetes mellitus in transgenic mice expressing human islet amyloid polypeptide. Proc Natl Acad Sci USA 93(14): 7283-7288.

11. Pillay K, Govender P (2013) Amylin Uncovered: A Review on the Polypeptide Responsible for Type II Diabetes. Biomed Res Int 2013: 1-17.

12. Westermark P, Engstrom U, Johnson KH, Westermark GT, Betsholtz C (1990) Islet amyloid polypeptide: pinpointing amino acid residues linked to amyloid fibril formation. Proc Natl Acad Sci USA 87(13): 5036-5040.

13. Anguiano M, Nowak RJ, Lansbury PT (2002) Protofibrillar islet amyloid polypeptide permeabilizes synthetic vesicles by a pore-like mechanism that may be relevant to type II diabetes. Biochemistry 41(38): 11338-11343.

14. Kayed R, Sokolov Y, Edmonds B, McIntire TM, Milton SC, et al. (2004) Permeabilization of lipid bilayers is a common conformationdependent activity of soluble amyloid oligomers in protein misfolding diseases. Journal of Biological Chemistry 279(45): 46363-46366.

15. Huang CJ Lin CY, Haataja L, Gurlo T, Butler AE, et al. (2007) High expression rates of human islet amyloid polypeptide induce endoplasmic reticulum stress mediated beta-cell apoptosis, a characteristic of humans with type 2 but not type 1 diabetes. Diabetes 56(8): 2016-2027.

16. Zhang S, Liu J, MacGibbon G, Dragunow M, Cooper GJ (2002) Increased expression and activation of c-Jun contributes to human amylininduced apoptosis in pancreatic islet beta cells. J Mol Biol 324(2): 271285.

17. Janciauskiene S, Ahre'n B (2000) Fibrillar Islet Amyloid Polypeptide Differentially Affects Oxidative Mechanisms and Lipoprotein Uptake in Correlation with Cytotoxicity in Two Insulin-Producing Cell Lines. Biochem. Biophys. Res. Commun 267(2): 619-625.

18. Zraika S, Hull RL, Udayasankar J, Aston-Mourney K, Subramanian SL, et al. (2009) Oxidative stress is induced by islet amyloid formation and time-dependently mediates amyloid-induced beta cell apoptosis. Diabetologia 52(4): 626-635. 


\section{Your next submission with Juniper Publishers} will reach you the below assets

- Quality Editorial service

- Swift Peer Review

- Reprints availability

- E-prints Service

- Manuscript Podcast for convenient understanding

- Global attainment for your research

- Manuscript accessibility in different formats ( Pdf, E-pub, Full Text, Audio)

- Unceasing customer service

Track the below URL for one-step submission https://juniperpublishers.com/online-submission.php 